Article

\title{
The Evolution of a Consolidated Market for Neo-Traditional Chinese Contemporary Art ${ }^{\dagger}$
}

\author{
Iain Robertson
}

Sotheby's Institute of Art, London WC1B 3EE, UK; iainrobertson007@gmail.com

† Limitations: I will not examine the market for Chinese traditional brush painting, as it has its own specificity related to long-standing aesthetic ideals. I will not discuss, specifically, the global market for contemporary art. It is another distinct market for art in China, which has its own ecosystem rooted in the Western art market and art world. It will be introduced in order to create a background against which the recent neo-traditionalist movement can be explained. Transliteration note: I have adopted the standard form of transliteration of Chinese characters, Pinyin. I provide the written Chinese characters once for each transliteration, but not thereafter. The transliteration and Chinese characters appear in the notes. I have employed the traditional script in respect of proper names before the 1950s and thereafter the simplified form.

Received: 10 August 2020; Accepted: 16 November 2020; Published: 25 November 2020

\begin{abstract}
The purpose of this paper is to determine whether there is an incipient market in China strong enough to replace the global market for Chinese contemporary art. The (informal) market I have identified supports traditional methods of transaction and practice. It charts a course twixt slavish emulation of the past and unqualified acceptance of the present. To demonstrate the contemporary application of this trend, I introduce three case studies, which examine the attitude and behaviour of three Chinese artists active between 2005 and 2015. This period marks the transformation of China from an aspirant economic power to a self-confident advocate of Chinese values. The premise of this paper is that the China market today is moving towards a harmonious ideal rooted in Chinese thought. In the nineteenth-century art movement known as the Shanghai School, I have found a precedent for the evolutionary transformation of Chinese art from the traditional to the modern. This study will reveal how the Shanghai School market might be an exemplar for today's Chinese contemporary art market. I will refer to this historical model to show how conventional methods of creation, distribution and consumption can effectively be modernised. Another effort to culturally transform China was attempted a generation later in the southern city of Guangzhou. The movement, known as the Lingnan School, attempted to fuse Western-style realism with Chinese techniques and media. I argue that these two early attempts to amalgamate the traditional with the modern failed to metamorphose into a consolidated Chinese contemporary art market model. They have, instead, resulted in the co-existence of two corrupted models; the one, a diffident fusion of the past and the modern world, and the other a concerted alliance of nationalism and globalism.
\end{abstract}

Keywords: international contemporary art (market); modern art market; (neo) traditional art market; Lingnan School; Shanghai School; international contemporary art market; traditional; hybrid art market; Western centric; Sino centric

\section{Introduction}

The Chinese market for contemporary art is temporally bound to the period of economic reforms initiated by Deng Xiaoping ${ }^{1}$ in 1977 until the present (Wang 2013). The market to which both Chinese

\footnotetext{
1 邓小平.
} 
and Western commentators commonly refer is that which most closely corresponds to the international market for contemporary art. This market has an added dimension. It is described as an ideologically transitional market in which the privatisation of art journals and the increasingly liberal and commercial behaviour of critics moved its axis towards a Western-centric model (Wang 2013). The interest of Westerners in Chinese art was piqued after 1989 by political sympathy for dissident resistance to the Chinese government, confirming the understanding between international contemporary art and liberal democracy (Leduc 2018; Chang 1993). There are various stylistic ways in which these commentators differentiate Chinese artists from international artists. One way is to add to 'contemporary' the prefix, 'Chinese'. Another is to draw a distinction between Chinese artists who operate in the international art market and those who remain national entities (Elliot 1993; Chang in Navarra 2001). The artist, Zhang Huan ${ }^{2}$ (b.1965), has said that in the Western art world "Chinese' always comes before 'art" (Hearn 2013, p. 15). Some scholars view Chinese painting as image making in the Chinese style with a Chinese medium, while others include imported styles and media. The mysterious landscape and the painted scroll, Gao Shiming writes, enjoy a symbiotic relationship in Chinese art (Gao 2011). This prompts Kuo to ask, how long can cultural tradition be re-interpreted before it is subverted (1984 colloquium in Hong Kong, in Kuo 2010). Barrass (2002) makes a distinction amongst calligraphers between revivalists, modernists and avant-gardists. More recently, since the global auction house sales triumph of individual Chinese artists from 2005 to the present and the earlier critical success of a coterie of émigrés, a handful are regarded as simply contemporary artists. The recent investigation into the market for contemporary art in China by Wan (2020) emphasises its links to the Western-centric auction market. In the same way, the performance of Chinese dealers is judged primarily by their success in international and regional fairs. China's new museums are treated like their Western counterparts (Tong 2020). There is still a significant direct Western involvement in much of the China market, and even when the instruments are Chinese, the mechanism and analysis are Western centric. The Chinese characteristics are stylistic, not systemic.

To be clear, contemporary art today is a product of the society in which it is made and the impact of globalisation is limited by assertive national values and deep societal mores (Robertson 2011). Today's China is much altered from the country that liberalised its economy in the late 1970s. The Chinese market for contemporary art today is rapidly reasserting its national character, and this is taking a traditional form. But, at present, the market is bifurcated; in some instances, it leans towards an earlier Shanghai School-type Sino-centric model; and in others, it takes the form of the Lingnan School-type Sino-Western fusion model. The other part of the market is aligned to the Western-centric market place. This market is again divided into two parts. One half comprises artists and institutions that adhere to the ideology of an individualistic, rights-based doctrine, which is aligned to a neo-liberal economic imperative. The other half is composed of those who broadly support, or at least do not contradict, the politics of China, but use the Western-centric market mechanism to make their fortune. I do not intend to further complicate the picture by introducing a third market made up of the great quantity of traditional brush painting created in civic brush painting societies throughout China, except to say that this production is, according to the leading art data indices, ArtPrice and Artron (Wan 2020), the largest quantitative component of the contemporary art market in China. Its art is either ideologically neutral or supportive of the Chinese government. The artist society ${ }^{3}$ has a long history in China, and is close in flavour to European artists' guilds. These institutions were transformed into organs of state under the Communist government, manufacturing an art commonly referred to, since the early twentieth century, as national painting. ${ }^{4}$ The focus of this paper is, therefore, the two constituents of the market

\footnotetext{
洹. 
for traditional-style art, the genesis of which, I believe, lies in the Shanghai and Lingnan Schools. These two markets represent, in a sense, the ideological battlefield of contemporary art in China today.

\section{The Sino-Centric Shanghai Model: An Example of the Evolution of Traditional Methods of Art Practice and Transaction}

The Shanghai art world of the late nineteenth century is a good example of the confluence of two civilisations, that of Europe and China, but also two ideologies-a Western colonial/mercantile mindset and a Chinese fin de la dynastie outlook. Chinese thought during this period was afflicted by the disturbances wrought by internal revolution (the Taiping Rebellion, ${ }^{5}$ 1853-1864 and a Muslim-led uprising in Yunnan, ${ }^{6}$ initiated by a sect calling itself The White Lotus, known as the Du Wenxiu Rebellion $^{7}$ (1856-1873)) and external invasion (the Opium Wars 1842 and 1864). ${ }^{8}$ The superiority of Chinese culture in the Chinese mind was still secure, but shaken at each stage by the failure of its military to counter British military superiority. ${ }^{9}$ After the 1878 Convention of Chefoo (now Yantai), two distinct approaches to the threat from without had emerged; self-strengthening and surrendering (Fenby 2008). ${ }^{10}$ In the Post Boxer phase (1898) until the collapse of the Qing (1912), there was institutional change. From the formation of the Republic to the New Cultural Movement (1915-1921), there was a shift in intellectual thinking. How could Chinese culture be re-directed to support the country's modern transformation (Fung 2010)? But, in the late 1880s, the instinctive response of many notable Chinese artists was to recreate a traditional Chinese cultural order ${ }^{11}$ in a modern, colonised metropolis. ${ }^{12}$

Late nineteenth-century Shanghai mirrored, in many respects, Haussmann's Paris (1853-1870); it had a substantial French concession, ${ }^{13}$ but also a glittering and modern civic life. Into this pulsating pleasure ground stepped a number of highly educated Jiangnan ${ }^{14}$ artists, who embodied the grand tradition, learnt in the cultural bastions of Suzhou ${ }^{15}$ and Hangzhou. ${ }^{16,17}$ The traditional learning ${ }^{18}$ culture operated a gift/exchange system known as an elegant gathering, ${ }^{19}$ which involved a studied,

\section{太平起义. \\ 云南.}

杜文秀起义.

8 The Qing Empire's Opium Wars鸦片战争with Great Britain highlighted in particular the enormous gulf in understanding between the maritime superpower and the sedentary empire. The British wished to establish trading concessions within China (which extended to the right to sell yapian 鸦片 (opium) sometimes known as yangyan 洋烟 (smoke from the Western seas)). The prefix yang 洋was a tribute to all things Western. They were opposed to the segregated, detached factories, and exasperated by the Qing's flouting of mutually agreed signed treaties. The Qing, who throughout treated the British as uncivilised, if technically superior, interlopers felt no obligation to correspond on an equal footing with their adversaries. Opium was a major grievance of the Taiping (a fundamental Christian army), as they reasoned that it was enslaving the Chinese, but the blame was increasingly shared by the Chinese towards the end of the nineteenth century and placed specifically on the 'weak' Qing government (Lovell 2011). Fenby (2008, p. 10) refers to fin de siècle China as 'an informal empire of foreigners in a country too big to be colonized'.

9 Karl Marx observed that late-Qing-dynasty China was bound to disintegrate when it met the glare of outside light, 'like any mummy carefully preserved in a hermetically sealed coffin' (Fenby 2008, p. xxxi).

10 Self strengtheners (1860-1894), yiyi zhiyi 以夷治夷 (learning from Barbarians to deal with Barbarians) (Fung 2010), had to demonstrate that they were improving China by employing Chinese methods while the surrenderists were accused of selling off the empire's assets.

11 The Chinese cultural order is overseen by an eternal Mandate of Heaven underpinned by its rites encoded by Confucius in his Great Learning.

12 Wan Qingli observes that political decline does not equate to a decline in art and thought.

13 上海法租界.

14 江南. A province in Southern China.

15 苏州.

16 杭州.

17 A Chinese metropolitan bureaucrat (a cultivated literati) who successfully passed the Imperial examinations had to memorise tens of thousands of characters, which included Confucius' Analects, Doctrine of the Mean, Great Learning, Mencius and the Five Classics of Poetry, Documents and Changes, the Record of rites and the Spring and Autumn annals.

18 guoxue国学.

19 yaji 雅集. 
informal but ritualised conversational interaction within a garden setting. The artist, Wu Changshuo ${ }^{20}$ (1844-1927), Wue (2014) explains, would often exchange his carved seals for a painting by a fellow artist he admired. It is significant that this request could not be denied. Portraits were regarded as particularly meaningful tokens of friendship in which the act of making and giving superseded the monetary value of the work. The high level of cultivation of all those who participated in this exchange determined its effectiveness. Any tangible benefit that the artist might secure would come at a later time. The art ecosystem consisted of professional art dealers who sold their wares on-spec in shops to international consumers; guilds that protected the artist's reputation and the price of his work; mass printing of imagery by lithography; and critical reviews in the commercial mass media.

When the literati fled the upheavals wrought in Southern China by rebellion, they encountered a different social ecosystem, but one in which confidence and assuredness in the value of (Chinese) culture $^{21}$ was still implicitly understood (Wue 2014). But, the traditional Chinese art world was forced to make concessions; greater than the changes that affected the art itself. ${ }^{22}$ These ranged from the representation of artists' work by specialist art suppliers (owners of fan- or paper-mounting shops ${ }^{23}$ ) and its immediate sale in exchange for money, which had, according to Wue, existed since the Ming dynasty (1368-1644). Some in Shanghai also offered cures for opium addiction! These shops, according to Wue (2014), operated inside and outside the concessions ${ }^{24}$ and behaved as 'prototypical dealers' and a 'mediating entity between buyers and artists' (p. 69). The work of art would henceforth be initially acquired through a professional intermediary for money and later, as likely, bestowed on a friend or an acquaintance as a gift or in order to fulfil the obligation of the giver. ${ }^{25}$ The new art world gave rise to an accessory industry of painted seasonal fans and also to the display of works in an elongated hanging scroll format (Wue 2014), whereas paintings would formerly have been acquired on inspection at an elegant gathering in a scroll or album form. It featured the introduction of $2 \mathrm{~B}$ pencils and the foreign carmine (red) pigment. Some fan shops held price lists and sold to East Asian clients. It is also noteworthy that the fan became a necessary accoutrement to a modern Shanghai 'gentleman' and as ubiquitous as the umbrella. Both items signalled the changed social behaviour of the modern Chinese city dweller. A new equality was promoted between agriculture and commerce. ${ }^{26}$ The new internationally focussed entrepreneurs accelerated the evolution of relationships, which would later emphasise commerce. ${ }^{27}$ Yet, a critical element in the reputation enhancement of artists was the demonstration of their literati credentials and it is this, as Wue (2014) explains, that led to the accusation that the Shanghai School was disingenuous. The example that she gives to illustrate this phenomenon is the painting by Ren Bonian ${ }^{28}$ (1840-1896) 'Picture of Three Friends' (1884) in which the artist is seated in gentlemanly conversation with the art dealer Zhu Jintang and another friend, Zeng Fengji. ${ }^{29}$ The scrolls and albums stacked on a nearby table 'represent the sitters' mutual

20 昌.

21 wenhua 文化.

22 Those pictorial amendments were nevertheless important. Wue (2014, p. 21) writes that the work is 'emphatically visual', and imagery on fans is suggestive of the fleeting movement. The dynamic composition of the paintings on the Shanghai fans has been interpreted by Hay (1994) as responding to urban sensations, such as speed, height and movement. The painting styles of Haipai artists are described in the lexicon of terms used for traditional brush painting; xieyi写意 (sketchy) is often used, but the subject matter changed. Bourgeois subjects such as birds, flowers, still life, the theatre and folk tales replaced traditional genre. The fan itself is an accessory and as such is accorded a lesser cultural value to a scroll painting. The artist, Hu Gongshou, Wue (2014, p. 33) writes 'effectively shrank down a landscape composition, reducing the large-scale elements of mountains, water, and trees and translating them to an urban garden context.'

23 jianshanpu鉴赏铺, biaohuadian裱画店.

24 A concession was a foreign enclave in Shanghai, which existed from 1845 to 1863 when they became settlements.

25 guanxi 关系or relationship is a cornerstone of Chinese social interaction, life and society. The connecting social web is developed out of family relations and extends, through 'professional' gatekeepers, to outsiders (Robertson 2018b). Successful exponents of guanxi have personal charisma and prestige, are sincere and fulfil their obligations (Johnson 2018).

26 yinong yishang 亦农亦商.

27 zhongshang zhuyi 重商主义.

28 任.

29 曾梵志. 
connection on profound levels of friendship, learning, and social status.'(Wue 2014, p. 1). Zhu Jintang was the owner of a paper and fan shop called the Hall of Nine Treasures ${ }^{30,31}$ situated in the foreign concession and may have been Ren Bonian's de facto agent. The artist, Wue (2014) argues, is now regarded as maker and entrepreneurial entity but with an implicit social function; to which I would add, a growing self-consciousness.

It is clear from contemporary commentaries that artists were acknowledged (critically) and recompensed (commercially) for their respective abilities in different genres. Artists also acquired appellations such as ink guests or scholars, ${ }^{32}$ famous calligraphers and painters ${ }^{33}$ and particularly famous gentleman, ${ }^{34}$ an archaic term with literati associations, which enhanced their credibility.

The dissolution of the Chinese art world as its own centre and whole (Wue 2014, p. 219) consigned ink painting and its traditional hierarchy of subjects to one medium among many: oil painting, graphic design, photography and European style print making. Further Western imports followed: art schools, journals, museums and exhibitions.

\section{The Fusionist Sino-Western Canton Model: A Modernist-Inspired Chinese Aesthetic Experiment}

There is much to admire in the aims of the Lingnan School (literally: south of the mountains), an art movement which originated in the provinces of Guangxi ${ }^{35}$ and Guangdong. ${ }^{36}$ It represented the ambitions of a narrow, technocratic (and ambitious) elite engaged in what it believed to be national self-improvement. The ideology of the Lingnan School (there was no written manifesto), unlike the Shanghai School, was self-consciously modern and foreign. Mainland Chinese scholars suggest, Fung asserts (2010), that liberalism, cultural conservatism and Marxism were actively investigated during the Republican period. Certainly, there are elements of post May the Fourth Movement ${ }^{37}$ Westernisation and anti-traditionalism in the Lingnan School, but the objective was cultural synthesis. Fung (2010) refers to this hybridity as returning to the roots in order to be creative and new ${ }^{38}$ and creating something new in order to strengthen the core. ${ }^{39}$ These two directions, Fung (2010) reminds us, were also tenets of neo-Confucianism. This structured, self-conscious approach to reform is very different from the clash of cultures experienced in Shanghai in the late nineteenth century, which was empirical, apolitical and evolutionary. The movement appeared a generation later than the Shanghai School and was heavily indebted to the Republican reforms of the Guomingdang ${ }^{40}$ and its cultural and political leaning towards Meiji Japan. It was closely connected to the anti-Manchu Movement, and so was revolutionary. Intellectuals during this period were re-educating themselves to serve the new State with fresh principles, which Fung (2010) has identified as: cultural radicalism, cultural conservatism, reformism, nationalism, statism, state building, capitalist development, social justice, liberty and equality. With these new aims, Fung (2010) explains, came a series of individual freedoms, which were both philosophical and tangible and which were in direct opposition to China's communitarian traditions. Crucially, Fung (2010) observes, modernity looks to the future, placing little value on past practice and behaviour.

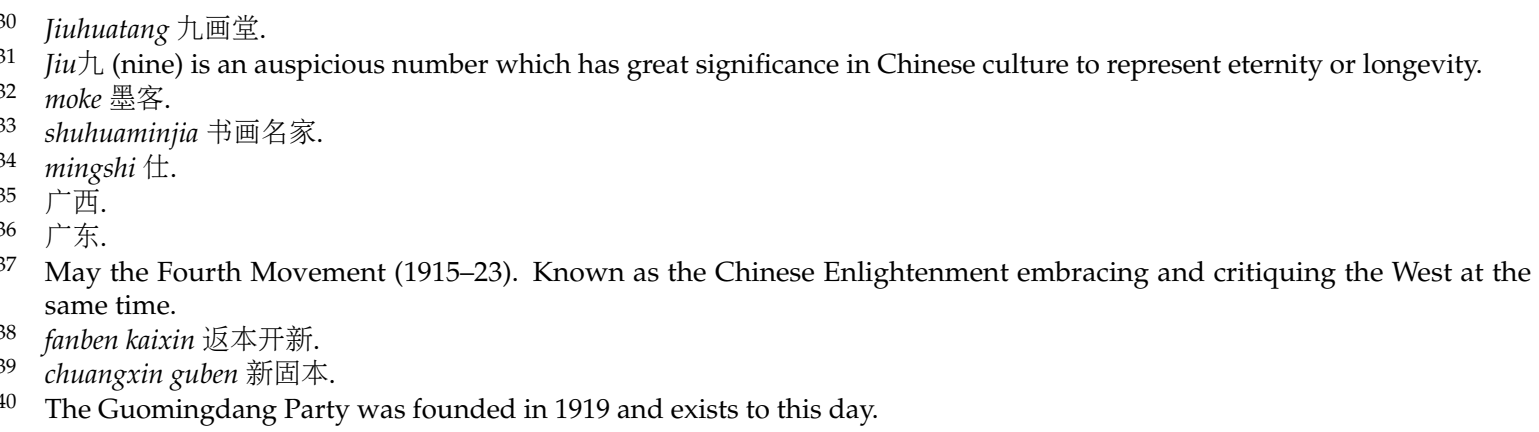


Two brothers, Gao Jianfu (1879-1951) and Gao Qifeng (1889-1933) together with Chen Shuren (1884-1948) ${ }^{41}$, were enraptured by the Japanese adaptation of Western culture to Asia. Nihonga (Japanese painting) influenced the new Chinese painting ${ }^{42}$ that the brothers introduced to China. All three artists were taught by a prominent Guangdong master Ju Lian (1828-1904). ${ }^{43}$ The artists lived with Ju, who operated a private academy called the Hall of the Whispering Lute at the time of the cultural abeyance of the Jiangnan region (Croizier 1992). Ju Lian, largely because of his pictorial and technical innovation in pen and ink painting, is regarded as greatly superior to another Cantonese artist, Lam Qua ${ }^{44}$ (1801-1860), who introduced, in the first half of the nineteenth century, an adulterated form of Western oil painting to Guangzhou. Ju's students were very influenced by his style of painting, but sought, on Ju's recommendation, further inspiration in Japan. While in Japan, Gao Jianfu appears to have fused Nihonga with the Realist art of Kyoto (Sullivan 1996; Croizier 1992). Sullivan (1996) relates that the brothers sought to merge world art into a style that would bring about an improvement to society. Gao Jianfu, according to McCloskey (2005), acknowledged the importance of Chinese traditions, but found it necessary to adhere them to Western approaches to make them vital. In 1912 Gao Jianfu showed his work, not in a fan shop, but in an exhibition at the Aesthetic Bookshop ${ }^{45}$ in Shanghai, and launched a political magazine, 'The True Record'. ${ }^{46}$ He pursued a career as a teacher in a government-run art school in Guangzhou at the behest of the nationalist leader Sun Yat Sen (1866-1925). ${ }^{47}$ In 1923, the brothers established their Spring Awakening Academy ${ }^{48}$ in order to promote new national art. Sullivan (1996) regards the painting as impassive and suggests that it was parochial and associated with Japan at a time of martial conflict between China and its island neighbour. The movement was the first in China to employ modern methods of academic teaching, and to use a new aesthetic vocabulary to address a modern subject matter, but it lacked deep roots and was swept aside by the succeeding Communist ideology.

The system which grew out from the Aesthetic Bookshop spread to public, provincial (Guangdong 1920) and national (Shanghai 1929) exhibitions, where it placed Western art beside national art. Modern education, which had been introduced by the Manchu reform in 1906, saw art taught as part of the educational curriculum, following the Japanese model. Cai Yuanpei $(1868-1940)^{49}$ was the first Minister for Education in Republican China and the first President of Peking University. Rosker and Natasa Vampelj (2013) assert that he stressed the importance of individuality, creativity and independent thinking. To counter these structural changes, painters' societies, such as the Shanghai Chinese Painting Society (f. 1931) ${ }^{50}$ persevered with traditional methods of instruction (Rosker and Natasa Vampelj 2013). The institutional approach to art education combined with the greater reach of art criticism, through the new mass print media, undoubtedly changed the manner in which artists viewed themselves and the function of their art. Gone was the elegant gathering; art was now re-purposed for ideological offense.

\section{The Sino-Centric Ideological Model}

Ralph Croizier (1990) explains that access of foreign collectors to Chinese modern art was accelerated in the 1980s and this resulted in a wider audience and broad appeal for Chinese art in general. This coincided with the opening up of China to the West. Chinese overtures to the West were

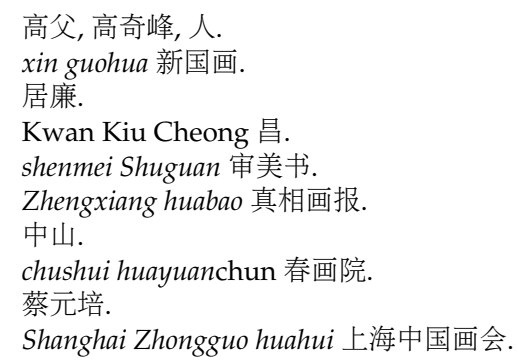


tempered after 1989. Johnson (2018) argues that the religious component to the new openness will be more lasting than were the political or even economic innovations.

By the 1990s, the Chinese state had reasserted its power throughout the country. At the same time, a skilful group of Chinese oil painters-many, graduates of the oil painting departments of the Chongqing and Beijing ${ }^{51}$ Art Academies-reversed the paradigm and painted images that would appeal to a Western audience. A handful of Hong Kong ${ }^{52}$ based and Western dealers sold their 'inverted Orientalist' (rather than Occidentalist) works to Europeans and Americans. ${ }^{53}$ The artists thereby forged commercial careers for themselves in the global contemporary art market, while remaining in China. This small coterie of dealers, who instantiated the myth of contemporary China, failed to convince the West's art world but persuaded its market. Today's Chinese artists have inherited this hard-nosed approach to sales success.

China's social/economic model has become more chauvinistic over the last two decades. Today's system is seen by the majority as a civilising force, one which President Xi Jinping ${ }^{54}$ has deployed in order to rid the country of absolute poverty, but also Minority traditions (Lu 2020). The incorporation of some of China's poverty stricken Minorities into a Han economic system ${ }^{55}$ sits beside the tacit approval that Chairman Xi has given to a revival of 'Chinese' (Han) religions and cultural practices (Johnson 2018). The new generation of Chinese artists and collectors — the second red generation ${ }^{56}$ —are turning to traditional 'Chinese' values with alacrity. Young collectors such as Lee Huina and Lu Xun are interested in Chinese art and also tradition. Many of these young collectors have filial connections to established family collections. Lu Xun is the son of Lu Jun, the owner of the Sino-centric Sifang museum in Nanjing. ${ }^{57}$ The Song Museum is an archetypal museum of this type. It houses the collection of Wang Zhongjun ${ }^{58}$, which is split evenly between Western modern masters, Chinese modern masters and Chinese contemporary oil painters. While this institution is based on the Western prototype, its content reflects the parallel interest that Chinese collectors have in two art histories.

Folk practices, ${ }^{59}$ from wood-block printing to paper cuts, from the burning of paper effigies at funerals to the modelling of the nationally symbolic Clayman Zhang figurines, have re-entered and re-vitalised mainstream Chinese popular culture. They have been activated in tandem with Chinese-specific internet platforms such as Baidu, Sina Weibo and Tencent (owner of WeChat). In fact, the live streaming from Weibo, Meipai and Douyun and the video platforms Meipai, Huaiao and Inke often project traditional values onto a new generation of Chinese. The internet celebrity, Lizhiqi, films her everyday life with her grandmother preparing classic Chinese dishes in a rural courtyard house. She boasts some 20 million followers. The power of internet reviews of films, for instance, can determine their success or otherwise (Peng et al. 2019). Chinese historical dramas, which are interminably long, are also consumed voraciously by a young audience. Much of the nuance, as is the case with popular culture, is sanitised. In her broadcasts, Lizhiqi appears to undertake an impossible amount of physical work, from rearing livestock to planting vegetables, to the effortless preparation of each meal. The historical dramas, likewise, are sketchy on detail, focussing instead on imagined social interactions. So, when we speak of China today, we refer to an increasingly homogeneous culture,

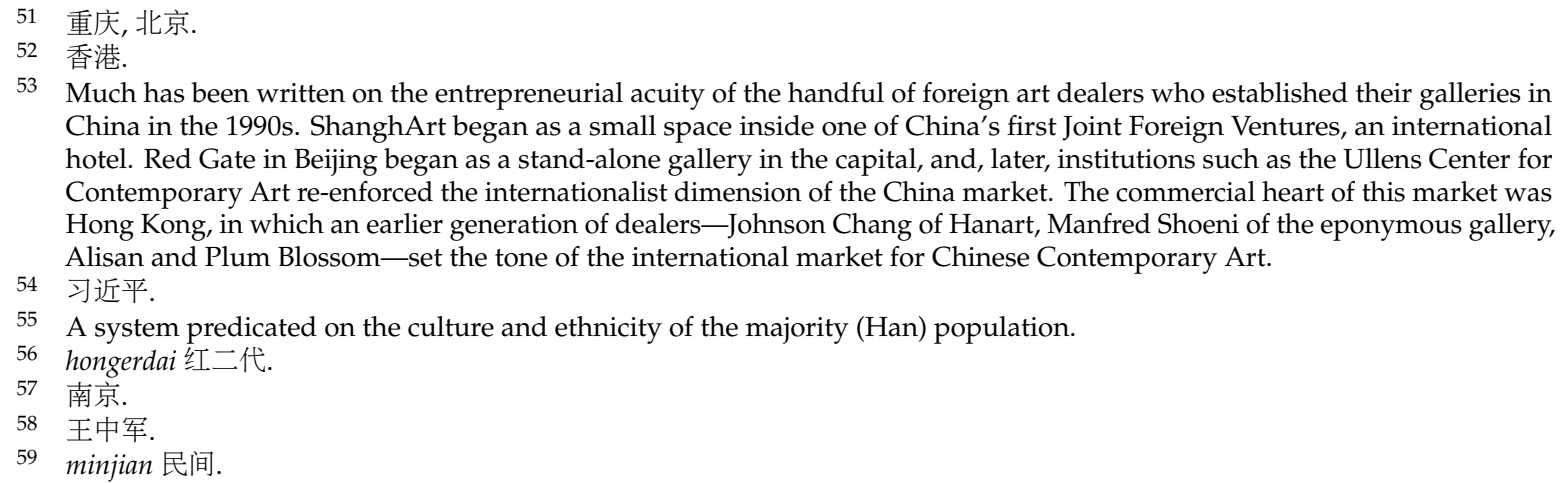


and a Party which seeks legitimisation from its tangible achievements but also endorsement from an idealised past.

But there are real grassroots efforts to stimulate a genuine revival of tradition in China. A revivification in the art of musical and ceremonial accompaniments to burials for instance. It is something that Ian Johnson (2018) recounts with great sensitivity in his account of the filial sweeping of the grave of a deceased family member. Tomb Sweeping Day ${ }^{60}$ is one of the most important festivals in the lunar calendar and the revival of its practice is a sign of the depth of this return to ancient ways. The other signal that society is reverting back to its instinctive cultural origins is the recurrence of mountain pilgrimages to honour gods and goddesses of the Buddhist and Daoist pantheons (Johnson 2018). It is important to know, as Johnson (2018) explains, that Chinese religions are the fabric of temporal life and not something that one professes as a single, exclusive faith; the Chinese are, historically, omnists.

The revival in religious practice in China would not have occurred without Document 19, a ten-page paper published in 1982 called 'The Basic Viewpoint and Policy on the Religious Question During Our Country's Socialist Period. ${ }^{\prime 61}$ The numbers that now adhere to a Daoist or Folk religion, according to Johnson (2018), approach 175 million added to the 300 million who follow one of the major faiths. This represents a ten-fold increase since the Document was first published (Central Committee of the Communist Party of China (CCCP) 1982). Later still, in the first years of the twenty-first century, Johnson (2018) recounts, the government raised the status of traditions such as music, cuisine, ritual, drama and martial arts, grouping them under the term intangible cultural heritage. ${ }^{62}$ The report makes a distinction between ethnic customs and traditions and religious activity, thereby reclassifying what might be regarded as Folk beliefs into cultural heritage (Central Committee of the Communist Party of China (CCCP) 1982). ${ }^{63}$ China's traditional heritage is regarded, as Johnson (2018, p. 79) writes, as a common spiritual garden for the Chinese nation. Funding for practitioners to teach their craft has also been forthcoming. ${ }^{64}$ Johnson makes the point that the Party is now smoothing over conflicts with traditional ideas. All these cultural developments mirror the systems that have operated for over seventy years in Japan and South Korea. Both those nations, and particularly Japan, now have vibrant craft markets and a way of life that has integrated the past with contemporary conduct. The particular talent that Johnson (2018) focuses on in his book is that of the yinyang ${ }^{65}$ men, who oversee burials. Their greatest skill, Johnson believes, is the writing of odes to the dead in hundreds of Chinese characters. It is this shared written culture of pictograms (Lindqvist 1991) that links the yingyang men to the shop sign craftsmen, the stonemasons who inscribe the steles of the dead and the increasing numbers of artists who choose to paint in pen and ink on paper.

\section{The Re-Interpretation of Tradition and Traditional Modes of art Transaction in Today's China}

One such artist, Li Jin (b.1958), ${ }^{66}$ demonstrates something more than a facility with a brush and great literacy; he shows an adaption of this ancient art form to contemporary life (J. Li 2010).

60 Qingmingjie 清明节.

61 Inherent to Document 19 is the understanding that the long-term goal of Socialism is to see an end to religion; but an acknowledgement that this will only happen slowly. In the interim, religious belief should be tolerated, if not encouraged. The aim is clearly to maintain stability and ethnic unity while developing international relations, but thwarting external infiltration. The criticism which is levelled at the Party is directed not at the core Communist belief in the eradication of Feudal values, which are believed to be inherent to religion, but the blanket suppression of religious gatherings by the Gang of Four (Lin, Biao, Jiang, Qing clique).

62 They are in effect a Folk art form of the 'religious professionals' that are identified in Document 19. This new group are also expected to perform a conservationist and curatorial role in safeguarding ancient (religious) buildings.

63 It is unclear in the report the extent to which the intertwining of religion and custom is the exclusive preserve of Tibetans (Lamaism) and Muslims, but in the case of the Han people, the division is declared to be quite clear.

64 The condition underlying religious expression is that it is propagated by an acknowledged association that has patriotic credentials. It is similar in that respect to the Brush Painting Society and Pilgrimage Association.

65 阴阳.

66 李津. 
Kuo (2010, p. 178) calls him an unorthodox New Literati. His art is certainly light hearted. It is also autobiographical and very descriptive. It is the seductive hedonism of his art, with its focus on self-gratification, which make it synonymous with the China of the post Deng economic reforms; the brush painting equivalent of Political Pop oil painting. Like the Shanghai School artists, who modulated their art and life to suit the realities of modernising Shanghai, so an artist such as Li Jin, a Beijing resident, accommodates his subject matter, style and flavour to a cutting-edge megalopolis. It is perhaps the versatility of the Folk tradition and art forms of China that is the most striking feature of the current revival. It is also noteworthy that in spite of the apparent tentacular reach of central government, there is a greater degree of autonomy the further that one is from the capital. Courty and Fenghua (2018) have shown how cultural participation has been uneven across thirteen Chinese cities. This allows for different art worlds and revivals throughout China. The artist Li Huasheng (1944-2018) ${ }^{67}$, who was resident in one of the last traditional houses in Chengdu, painted in a markedly different way to an equivalent artist in the capital. His environment was in many ways more genial than that of his Northern counterpart, Xu Longsen (b.1956), ${ }^{68}$ who resides in a bombastic palace on the outskirts of Beijing, where he devises huge landscapes, which he pastes to the wall of his cavernous studio. Whereas Li Huasheng would discuss his work with a group of cognoscenti over tea, his hanging scrolls distributed throughout his house, $\mathrm{Xu}$ Longsen orchestrates sumptuous elegant gatherings in his home in which the work of art is instrumental to the choreographed performance.

In order for these systems-particularly the colloquy and the theatrical elegant gathering-to work, old rules ${ }^{69}$ have to be understood by the participants. The elegant gathering today has changed and is much less intellectually exacting than it would have been a century ago. This is because it has re-surfaced in a changed China. Nevertheless, it is a morally acceptable and efficient hierarchical structure (Bell and Wang 2020), which privileges cultural status over economic wealth. The artist is accorded the leading social position ahead of the interpreters who are themselves considered more important than the collectors. One reason for this ranking is the privileging of soft skills; a significant level of literacy, an understanding of etiquette, conduct, proportion, entertainment and tea. In the same way as the 'gentleman's agreement', 'on consignment', 'commission', 'price on application', 'caveat emptor' and all the unspoken, unwritten social rules of transacting art in the Anglo-centric global art market bind its fabric together, so must other polite codes in a Sino-sphere. Beyond the intellectual requirements of the elegant gathering, there is a moral reason why a Westerner might find it hard to participate; namely, the inversion of the economic hierarchy in favour of the social-inequality hierarchy (Bell and Wang 2020). Johnson (2018) writes of a bottom line, ${ }^{70}$ or a minimum moral standard, which must be present if such an informal system is to operate successfully. A marriage of sincerity and learning in this Chinese art world is an essential concoction. The sentiment ${ }^{71}$ of the artist, intermediary and collector is implicit in good relations. In order for the sentiment to be credible, it must have human feeling ${ }^{72}$ offer face ${ }^{73}$ and show reciprocity. These are values that can only be observed over the time and the duration of a relationship, which is why the relationship guardian ${ }^{74}$ who introduces one to another is so significant.

When I sat (H. Li 2000. Interview 2), the fourth member of a quartet, listening to the conservation between the three protagonists in the house of Li Huasheng, much of the conversation was oblique; only occasionally referring to the hanging scrolls, which were displayed between two sets of chairs

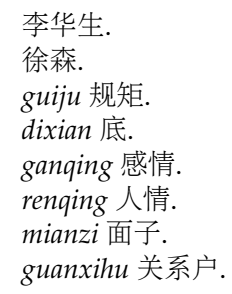


on opposite sides of the room. An aged $\mathrm{Pu}-\mathrm{er}^{75}$ tea enhanced the conservation. After two hours, the colloquy was abruptly curtailed and we passed through the artist's courtyard garden to his car and then to a restaurant to eat spicy Sichuan ${ }^{76}$ food. The hierarchy of our small convocation changed at the dining table. Four further people joined our quartet. In common with all formal Chinese dining occasions, we were seated at a round table. Li Huasheng, as principal host, was seated facing the door; $\mathrm{I}$, as guest of honour, was to his right. My two companions were seated, one (a senior academic) to the artist's left, the second guest of honour, and one facing the artist with his back to the door. The new arrivals were seated randomly. The business was conducted at the table towards the end of the meal, after two separate events had concluded-the conversation in the artist's house and table toasts. I do not know whether the pictures were sold on that day. ${ }^{77}$

When I arrived at the gates of Xu Longsen's white-walled mansion on the outskirts of Beijing (Xu 2015. Inteview 3), I was struck by the imposing bronze, seated Bodhisattva that was placed to one side of the entrance. Would that have been possible before 1982 and the publication of Document 19 ? Beyond the portal lay a courtyard with a moat, a bridge and haphazardly displayed sculptural and architectural ornaments. In the interior of the complex, many of the rooms were furnished with wooden panelling and modern Chinese oil paintings; reminiscent of early twentieth-century Republican interiors. ${ }^{78}$ The stairwells were hung with the artist's framed brush works. At the centre of the complex was a huge hall on the walls of which was pasted a vast landscape, comprised of many parts. A crane hoisted the artist and his audience to vantage points before this majestic piece of scenery. In conversation with $\mathrm{Xu}$, I learned that he would, when his paintings were completed, invite a select group of guests to his mansion, some of whom were collectors and others interpreters of his art. The event would be fuelled by alcohol and food and might continue into the early hours of the morning. I have referred (Robertson 2018a, pp. 16, 71-72, 94) to a more formal elegant gathering, which took place in the recreated (communal) garden space of Ye Fan's row of houses in Suzhou. On this occasion, an influential group of Chinese collectors from Taiwan attended a traditional en plein air musical concert, engaged in conversation, drank tea, ate food and acquired works of art by the artist. ${ }^{79}$ In both cases, the architectural space was significant, but so too were the quality and character of the participants. A measure of old rules and a bottom line had to apply.

There is a case to be made for the circumstantial adaptation of tradition today in a way that is not dissimilar to that undertaken by the Shanghai School artists and tea shops of the late nineteenth century. The modifications are, in the three examples that I have given, devoid of ideology, dismissive of foreign invention and intervention, and commercially motivated. The instruments of sale are different in each instance. Li Jin employs the mechanisms of a Western-centric market, but one that is Sino specific. His ink art that is sold through the Ink Studio (a Beijing art gallery) caters primarily to Chinese taste (J. Li 2016. Visit 1). Li Huasheng reverted to a pre-modern colloquy which is exclusively Chinese and Xu Longsen devises a more public, traditional demonstration of his art form, but again one that strongly favours Chinese collectors. In each case, as with the tea shops a century and half before, foreigners may participate in this world, but they would have to acquiesce to the Sino-sphere.

The question of the value and integrity of the art can in large part be answered by reference to artists' sincerity, legitimised by their commitment. A technical and aesthetic measurement of the merits of the art require a first-hand knowledge of Chinese brush strokes and calligraphy, and, according

75 普洱.

76 四川.

77 I am indebted to Bell and Wang (2020) for their diagrammatic and written explanation of a seating hierarchy at a Shandong dinner party and hope that my application of their system to my circumstance is equally valid.

$78 \mathrm{Xu}$ Longsen looks remarkably similar and dresses in a manner reminiscent of the former President of the Republic of China, Chiang Kai-shek (介石).

79 The members belonged to the Taiwan-based Ching Wan Society清雅集. Connoisseur antique and painting collecting societies are prominent in East Asia. Hong Kong has the Min Chiu Society敏求精舍, founded in 1960; and the Kau Chi Society求知雅 集, founded in 1979. It is noteworthy that both the Ching Wan and Kau Chi describe themselves as yaji (elegant gatherings). 
to Kuo (2010), the way in which the script is historically interpreted; all of which is inaccessible to most foreigners. Sullivan (1996, p. 254) regards the work of Li Huasheng very highly. He attributes a component of Li's superior artistry to his training in national and Western art ${ }^{80}$ by his master, Chen Zizhuang (1913-1976), ${ }^{81}$ whose style he 'absorbed' and went beyond. Li Huasheng was invited in 1980 to demonstrate his art before Deng Xiaoping; which might be regarded as the ultimate affirmation of his talent, except that the Chinese art establishment only very reluctantly and belatedly acknowledged the excellence of his work. A number of commentators hold views on the quality of modern and contemporary ink artists. Jason C. Kuo $(2010$, p. 11) observes that Chinese ink art has at its base calligraphy through which the artist 'attempts to revive the entire gestural movement and imaginative power of the signs.' He is in favour of the subversion of Chinese tradition, but within the bounds of Chinese history. This classification chimes with the instinctive approach of the Shanghai School artists and also of Li Huasheng. In fact, Kuo's acknowledgement of the struggle that Chinese artists face to assert the contemporary relevance of the work within the grand classical tradition, reflects the view of the scholar and dealer, Johnson Chang (1999), who favours contemporary expression over classicism, but acknowledges the central role that tradition plays in Chinese art, notably in the work of landscapists such as Xu Longsen (Chang 2018). Clarissa von Spee (2012) makes a distinction between internationalist, modernist and contemporary ink art that challenges the past. Maxwell K Hearn (pp. 13-14) writes of Chinese ink art, which has fundamentally altered inherited tradition while identifying with the expressive language of ink, as a subset of art created in China from the 1980s. Gordon Barrass (2002) calls the new generation who keep the classical ideals alive within a modern context-neo-Classists. The views of all these scholars appear to call into question the primacy of the traditional harmonious synthesis. But, as Huang Binhong (1865-1955) ${ }^{82}$ (the last literati painter) writes in Kuo (2010, p. 16), 'True learning lies not in the recycling of the past, but in learning the old and knowing the new.'

A neo-traditional, consolidated market that operates outside the Western-centric orbit, but that is responsive to the present, may become the core contemporary expression in China. It forms a sector of the Chinese market that offers Chinese contemporary art to Chinese collectors, free of historical emulation, but also of the ideology of global contemporary art. In order for this system to exist, there must be a broad societal and political consensus that the past has a significant role to play in contemporary China.

\section{Conclusions}

The Western-centric art ecosystem in China produced a national reaction and led to the rise of neo-traditionalism throughout the country. I acknowledge that neo-traditionalist art is sold through global art market mechanisms. Xu Longsen is represented by Hanart TZ, an international dealer based in Hong Kong, while Li Jin and Li Huasheng have both sold work through Christie's in Hong Kong. This may indicate regional division in the international market. It may also suggest that Chinese neo-traditional art is influencing global taste. I suggest that it reflects a comparable hybridity to that evident in Shanghai a hundred years ago. The difference being that today the region is more dependent on China than on the West.

Grassroots tradition in China is not myopic; it concerns wider human behaviour and customs. It thrives in an environment which encourages the revival of burial ceremonies, pilgrimages and superstition as well as religious belief. Out of this resurgence in traditional practice and behaviour will come the revival of Chinese traditional art, driven by the re-introduction of a system and received codes of behaviour that enable it to flourish. The amalgamation of modernity and Chinese tradition, which

\footnotetext{
xiyanghua 西洋画.

陈子庄.

虹.
} 
occurred spontaneously in Shanghai in the late nineteenth century, provides an excellent example of how a new Chinese art can revive its adulterated culture and dislocate itself from structural dependence on the West. It provides a better precedent than the Lingnan School, which was overburdened with ideology, time bound and parochial.

It is important to acknowledge that the world has changed irreversibly for China since the flourishing of national learning, but that the Shanghai School, if it had not been extinguished by the monumental and drastic internal and external forces that beset that civilisation in the twentieth century, would have provided a unique point of transition for China from tradition to modernity.

Funding: This research received no external funding

Conflicts of Interest: The author declares no conflict of interest

\section{References}

Barrass, Gordon. 2002. The Art of Calligraphy in Modern China. London: British Museum Press.

Bell, Daniel A., and Pei Wang. 2020. Just Hierarchy: Why Social Hierarchies Matter in China and the Rest of the World. Princeton: Princeton University Press.

Central Committee of the Communist Party of China (CCCP). 1982. The Basic Viewpoint and Policy on the Religious Question during Our Country's Socialist Period. Extracted from MacInnes, D. 1989. Religion in China Today: Policy and Practice. Beijing: CCCP.

Chang, Tsong-zung. 1993. Shedding the Burden of History. New Art from China Post 1989 in New Art from China: Post 1989. London: Marlborough Fine Art.

Chang, Tsong-zung. 1999. Power of the Word. Hong Kong: Hanart TZ Gallery.

Chang, Tsong-zung. 2018. Mountains in the Clouds. Hong Kong: Hanart TZ Gallery.

Courty, Pascal, and Zhang Fenghua. 2018. Cultural Participation in Major Chinese Cities. Journal of Cultural Economics 42: 543-92. [CrossRef]

Croizier, Ralph. 1990. Art and Society in Modern China-A Review Article. The Journal of Asian Studies 49: 579-602. [CrossRef]

Croizier, Ralph. 1992. Art and Evolution in Modern China: The Lingnan (Cantonese) School of Painting (1906-1951). Berkeley: Center for Chinese Studies, University of California.

Elliot, D. 1993. Silent Energy: New Art from China. London: Whitechapel Art Gallery.

Fenby, Jonathan. 2008. The Penguin History of Modern China: The Fall and Rise of a Great Power 1850-2008. London, New York, Ontario, Dublin, Victoria, New Delhi, North Shore and Johannesburg: Penguin.

Fung, Edmund S. K. 2010. The Intellectual Foundations of Chinese Modernity. Cultural and Political Thought in the Republican Era. Cambridge: Cambridge University Press.

Gao, Shiming. 2011. No Mountain too High: The Crisis of Landscape and Xu Longsen's Outsized Shanshui Experiments. Available online: www.xulongsen.com (accessed on 15 November 2020).

Hay, J. 1994. The Body Invisible in Chinese Art? In Body, Subject and Power in China. Edited by Angela Zito and Tani Barlow. Chicago: University of Chicago Press, pp. 42-77.

Hearn, Maxwell K. 2013. Past as Present in Contemporary Chinese Art. In Ink Art: Past as Present in Contemporary China. New York and New Haven: The Metropolitan Museum of Art and Yale University Press, pp. 35-71.

Johnson, Ian. 2018. The Souls of China: The Return of Religion after Mao. New York: Penguin Random House.

Kuo, Jason C. 2010. Chinese Ink Painting Now. New York: Distributed Art Publishers, Inc.

Leduc, Marie. 2018. The Rise of Chinese Contemporary Art in the West. Cambridge: The MIT Press.

Li, Huasheng. 2000. Interviewed by Iain Robertson in Chengdu. July 19, (Interview 2).

Li, Jin. 2010. Interviewed by Iain Robertson in Beijing. January 12, (Interview 1).

Li, Jin. 2016. Exhibition. INK Studio, Beijing, China, May 28-August 14. Visited by Iain Robertson in Beijing. June 4, (Visit 1).

Lindqvist, Cecilia. 1991. China, Empire of the Written Symbol. London: Harvill and imprint of HarperCollins Publishers.

Lovell, Julia. 2011. The Opium War: Drugs, Dreams and the Making of China. London: Picador an Imprint of Pan Macmillan.

Lu, Yufan. 2020. China's Race to Beat Poverty. Financial Times, June 26. 
McCloskey, Barbara. 2005. Artists of World War II (Artists of an Era). Westport: Greenwood Press.

Navarra, E. 2001. Made by Chinese. Paris: Hanart T Z Gallery Hong Kong, Galerie Enrico Navarra.

Peng, Fei, Kang Lili, Anwar Sajid, and Li Xue. 2019. Star Power and Box Office Revenues: Evidence from China. Journal of Cultural Economics 43: 247-78. [CrossRef]

Robertson, I. 2011. A New Art from Emerging Markets. Farnham: Lund Humphries.

Robertson, I. 2018a. New Art New Markets. Farnham: Lund Humphries.

Robertson, I. 2018b. A Comparative Study of the Influence of Political Systems on the Art Markets of East Asia and China. The Journal of Arts and the Market 8: 123-36. [CrossRef]

Rosker, Jana S., and Suhadolnik Natasa Vampelj. 2013. Modernisation of Chinese Culture: Continuity and Change. Newcastle upon Tyne: Cambridge Scholars Publishing.

Sullivan, Michael. 1996. Art and Artists of the Twentieth Century China. Berkeley: University of California Press.

Tong, Yaqi. 2020. How Chinese Museums are Coping with Coronavirus: An in-depth report. The Art Newspaper, March 4.

von Spee, Clarissa. 2012. Modern Chinese Ink Paintings: A Century of New Directions. London: The British Museum Press.

Wan, Jie. 2020. The Market in 2019. In Chinese Painting and Calligraphy: Better Painting, Fewer Lots. Available online: ArtPrice.com or Artron.com. (accessed on 15 November 2020).

Wang, Peggy. 2013. Art Critics as Middlemen. Navigating State and Market in Contemporary Chinese art, 1980s-1990s. Art Journal 72: 6-19. [CrossRef]

Wue, Roberta. 2014. Art Worlds: Artist, Images, and Audiences in Late Nineteenth-Century Shanghai. Hong Kong: Hong Kong University Press.

Xu, Longsen. 2015. Interviewed by Iain Robertson in Beijing. July 5, (Interview 3).

Publisher's Note: MDPI stays neutral with regard to jurisdictional claims in published maps and institutional affiliations. 